consultants in the Faculty of Public Health Medicine. As some public health tasks cannot be accomplished in primary care, and if Hart is right, to make community oriented primary care a reality requires major changes in the work patterns in both primary care and public health medicine, and substantial funds.

rofessor ofepidemiology and

Department of Epidemiology and

Public Health,

School of Health Care Sciences,

University of Newcastle,

Newcastle upon Tyne NE2 4HH

1 Bhopal RS. Public health medicine and primary health care: convergent, divergent, or parallel paths? $f$ Epidemiol Community Health (in press).

Pollock Health (in press).

BMF 1995;310:481-2. (25 February.)

(25 February.) Hart JT. A new kind of doctor: the general practition
health of the community. London: Merlin, 1988.

4 Mant D Andermunity. London: Merlin, 1988. 1985; ;i: 114-7.

5 Shanks J, Kheraj S, Fish S. Better ways of assessing health needs in primary care. BMF 1995;310:480-1. (25 February.)

6 Russell EM. Community medicine and primary care in Scotland. Community Medicine 1988;10:112-6.

\section{Professional negligence}

\section{Negligence cannot be decided by offending doctor}

EDITOR,-As a doctor with some experience as an expert witness in writing reports on medicolegal cases I agree with the general thrust of the editorial by Jean Ritchie and Sally Davies: that doctors should be candid to patients and carers about the progress or otherwise of their patients. ${ }^{1}$ However, the article continually mentioned the desirability of doctors disclosing to patients if they have been "negligent." That is wrong. Whether a doctor has or has not been negligent can only be decided by others (a court of law, the General Medical Council, an inquiry, etc).

As expert witnesses writing reports we conform to careful practice in coming to an opinion as to whether or not practitioners in the case under review were negligent or not. In coming to this opinion we have in mind various legal guidelines framed in famous judgments such as Bolam $v$ Friern Hospital Management Committee, Whitehouse $v$ Jordan, and Wilsher $v$ Essex Area Health Authority. ${ }^{2}$ As the judgment of Lord Fraser in Whitehouse $v$ Jordan makes clear, there can be an error made by a skilled person acting with ordinary care that is not negligent.

I was interested to learn that lawyers are under constraint according to their code of ethics to inform their clients if they feel that they have handled their case negligently. It is strange how seldom one hears or reads of such conduct being spoken of or recorded.

Doctors should be candid to patients and carers when things go wrong and when the doctors feel things could have been done better, but that does not mean that they have a duty to apportion blame either on themselves or on colleagues. If they are involved in the case they are the last people who should be required to do this as they would not be able to apply the necessary objective approach that must accompany any matter of judgment. So, it should not be a duty for doctors to report their negligence to patients and carers. As the subtitle for the leading article says: doctors should explain in full when care has gone wrong.

R H DAVIES

Gwynedd Community NHS Trust,

Consultant

Tregarth,

Gwynedd LL57 4PW

1 Ritchie JH, Davies SC. Professional negligence: a duty of candid disclosure? BMF 1995;310:888-9. (8 April.)

2 Dando P. Resuscitation-some medico-legal problems. fournal of the Medical Defence Union 1992;1:5-6.
Doctors may make mistakes that are less obvious than lawyers' mistakes

EDITOR,-The sentiments expressed by Jean Ritchie and Sally Davies are laudable but raise two important matters which were not addressed by the authors. ${ }^{1}$

The authors refer to "mistakes" and to care which has "gone wrong" as though these were invariably self evident. A lawyer's missed deadline for issuing a writ or a motorist's dented vehicle may easily be recognised as evidence of mistake. It will readily be conceded that amputation of the wrong limb or a gross overdose of a medicine through a misplaced decimal point are, similarly, easily recognisable mistakes. However, most allegations of medical negligence arise from therapeutic interventions or omissions which are not self evidently mistakes or evidence of care having gone wrong. Those whose professional judgments are to be called into question may be forgiven for failing to recognise as mistakes or evidence of care having gone wrong acts and omissions which, though criticised by some, unquestionably have the full support of responsible colleagues of similar training and experience. It would be helpful if the authors could translate the fine sentiments which they express into more tangible practical guidance for members of the medical profession who endeavour to serve the interests of their patients with commendable skill and integrity.

The concept of negligence is not without difficulty for most medical practitioners. The teaching of forensic medicine is no longer part of the medical curriculum and negligence as a civil tort is poorly understood. Our experience is that most doctors who are accused of it still equate it with neglect and do not understand the true legal meaning of the term. One of the principles of natural justice is that no man should be a judge in his own cause. Consequently it is not for the individual clinician to decide whether or not he or she has been negligent - that is a judgment to be made by others. On current tort principles, the allegedly negligent practitioner may well find that he or she has support from colleagues who have reviewed all the facts and the records in response to a formal request for an opinion.

By all means encourage clinicians to give full honest, and objective information to patients at all times, and especially in response to adverse outcomes which follow therapeutic interventions However, do not cloud the issue by reference to subjective considerations ("mistakes") and lega concepts ("professional negligence") which are imprecise and unclear to those at whom they are directed.

Medical Protection Society,

R N PALMER

London W1N 6DE

1 Ritchie JH, Davies SC. Professional negligence: a duty of candid disclosure? BMF 1995;310:888-9. (8 April.)

\section{Candid disclosure is right}

EDITOR,-At first reading we thought the editorial by Jean Ritchie and Sally Davies ${ }^{1}$ was in response to the wave of antilawyer jokes that has swept North America-for example, "What would you call 100 dead lawyers at the bottom of the sea?" "A good start"; the new version presumably is: "What would you call 100 lawyers owning up to the truth?" "A new beginning, or perhaps a miracle." Nevertheless, better late than never. It was, after all, medical defence lawyers who, until recently, wanted to treat medical accidents like motor vehicle accidents and impressed on all concerned that they should not admit any liability. ${ }^{2}$

Ritchie and Davies reiterate most of the points that were in our 1986 guidelines as to what to do if things go wrong, ${ }^{3}$ but they have missed one crucial item. The main reason for candid disclosure is because it is right. Doctors should provide "full disclosure of facts." Patients and families want and need that, as well as some "reassurance that a similar accident will not happen to someone else." The avoidance or mitigation of lawsuits is a secondary consideration. ${ }^{4}$

In our experience it is essential that a doctor (regardless of seniority) involved in an incident discusses the matter with other colleagues. ${ }^{3}$ This should be done, if possible, before meeting with the patient or relatives. Reasons for this include the difficulty the doctor affected may have in deciding alone what is the truth of the matter; that the doctor cannot conduct any necessary investigation of the case in an unbiased fashion; and, if the event has an adverse outcome, the issue of counselling for the doctor. ${ }^{5}$ LSTRUNIN

Anaesthetics Unit,

Royal London Hospital

London E1 1 BB

Department of Anaesthesia,

J

Foothills Hospital,

Calgary, Alberta T2N 2T9,

Canada

1 Ritchie JH, Davies SC. Professional negligence: a duty of candid disclosure? $B M 7$ 1995:310:888-9. (8 April.)

Davies JM, Strunin L. When things go wrong. Part I. Doing what is right for the mutual interest of the doctor and patient. what is right for the mutual inte

3 Strunin L, Davies JM. Doing what is right in anesthesia. Can Med Assoc F 1986;134:1232.

4 Davies JM, Eagle CJ. Risk management: the operating room: a multidepartmental model. Ann RCPSC 1994;27:153-6.

5 Davies JM, Bacon AK. When things go wrong. Part II. Doing what is right for the psychological well-being of the anesthesiologist. Anesth Rev 1990;XVII:50-3.

\section{Ethics and economics of health care}

\section{Prognosis, a traditional alternative to futility}

EDrToR,-The editorial by Charles Weijer and Carl Elliott and by Richard Smith raised important questions about the ethics and economics of health care. ${ }^{12}$ Weijer and Elliott drew attention to the shortcomings of the new and fashionable concept of futility. ${ }^{1}$ Medicine, however, is a venerable profession and doctors already have suitable concepts in our traditional toolkit-namely, an awareness of the importance of establishing a precise diagnosis and prognosis. A decision about appropriate treatment can then by taken, after discussion with the patient or a child's parents. It is neither necessary nor appropriate to invoke the issue of rationing limited resources at that stage.

I think that it was here that the arguments about B, the child with leukaemia, became confused. ${ }^{3}$ The doctors looking after $\mathrm{B}$ had come to a diagnosis and prognosis. Cambridge Health Authority muddled the issue by invoking two separate arguments for not funding further treatment. Firstly, that treatment would cause B suffering that would be unjustified when set against a $10 \%$ chance of success. Secondly, that the treatment would not have been "an effective use of resources." Regrettably the Appeal Court did not clarify the issue. How much better it would have been if the Appeal Court's judgment had reaffirmed the views of the House of Lords Select Committee on Medical Ethics, which stated that "health-care teams should not be put in a position of having to make such decisions in the course of their day-to-day clinical practice. Their concern must be for the welfare of the individual patient."

The challenge to clinicians, when dealing with an individual patient, is to derive as precise a prognosis as possible on the basis of the available scientific evidence, and then to act in the best 